\title{
A Study of the Determinants of Cost and Revenue Efficiency in the Context of Islamic and Conventional Banks: The Case of Malaysia from 2006 to 2012
}

\author{
Mohamed Ghroubi ${ }^{1}$ \& Ezzeddine Abaoub ${ }^{2}$ \\ ${ }^{1}$ Higher Institute of Theology, Ez-Zitouna University, Tunisia \\ ${ }^{2}$ College of Administrative and Financial Studies, Taif University, Taif, Kingdom of Saoudy Arabia \\ Correspondence: Mohamed Ghroubi, Higher Institute of Theology, Ez-Zitouna University, Tunisia. E-mail: \\ medghroubi@gmail.com orghroubi_m2002@yahoo.fr
}

Received: April 6, 2016

Accepted: May 3, 2016

Online Published: June 25, 2016

doi:10.5539/ijef.v8n7p258

URL: http://dx.doi.org/10.5539/ijef.v8n7p258

\begin{abstract}
In this paper, we examine the determinants of cost and revenue efficiency of Malaysian banks over the period 2006-2012. Three steps are undertaken to study a sample of 17 Islamic banks (IBs) and 20 conventional banks (CBs). In the first step, we assessed the competitiveness of the Malaysian banking sector. After solving the multicollinearity problem, as a second step, we selected three sets of independent variables: bank-specific, industry-specific and macroeconomic variables. In the last step, we estimated the efficiency models with the Feasible Generalized Least Squares (FGLS) method. The obtained results highlighted the importance of regulatory capital and size. As for the effect of competitiveness, it is found to be statistically significant only for revenue efficiency. These results may be useful to political decision-makers and regulatory authorities.
\end{abstract}

Keywords: Islamic banks, conventional banks, cost and revenue efficiency, meta-frontier analysis, capital, market competitiveness, credit and liquidity risk

\section{Introduction}

The success of the Malaysian banking system in surviving the "subprime" crisis with the least damage reflects the significance of the different monetary policies adopted by policymakers and supervisory authorities since the 1997 Asian crisis. Developing Islamic financial intermediation is part of these policies.

Indeed, today Malaysia is considered among the leaders of Islamic finance. Its prominent position resulted from the political choices undertaken by the successive cabinets of Mahathir Mohamed. It was in 1980 that the decision to support Islamic finance in Malaysia has become political. This date marks the event of adopting the "Islamic Banking Act" which provides a legal framework for the creation of IBs. The new practice of Islamic finance in Malaysia was initiated as an experiment that lasted ten years in which one bank was created; it was the "Bank Islam Malaysia Berhad". Following this period, the door was open for a rapid development of Islamic finance. In 1993, the government launched the "Interest Free Banking Schema" authorizing CBs to open "Islamic windows" benefitting from management and accounting practices that are independent of those of CBs. In 2004, the government decided, as part of a strategy to liberalize the banking sector, to grant new licenses for foreign IBs mainly from the Gulf countries. As a result, the number of IBs in 2012 reached sixteen banks in addition to ten Islamic windows (Note 1).

As part of its regulatory role, in 1997 the Bank Negara Malaysia (BNM) created, the Shariah Advisory Council whose role is to ensure that the financial products held or newly conceived by Islamic financial institutions comply with the Sharia principles. In addition, the Malaysian capital (Kuala Lumpur) was chosen to host the headquarters of two international organizations monitoring the stability and solidity of the various Islamic financial institutions. These organizations are the "International Islamic Liquidity Management Corporation", created in late 2010 to manage cross-border liquidity, and the Islamic Financial Services Board (IFSB) established in 2003 as the official international body supervising the Islamic economic sphere. Malaysia has also managed, through a more flexible interpretation of Sharia requirements, to create in 1994 an Islamic Interbank Money Market and to design various Shariah-compliant instruments. Among these instruments are the "Mudharabah interbank investment", the "Bank Negara Negotiable Notes" and "Islamic Treasury Bills" issued 
by BNM and "Government Investment Issues" issued by the Malaysian state. Malaysia has, moreover, is ranked globally first in terms of issuing sukuks. Indeed, despite the disruption of the world economy due to the recent financial crisis, Malaysia has continued to be a key participant in the global sukuk market with a $74 \%$ issue rate in 2012 (71,6\% in 2011) of the total sukuks emissions, ahead of Saudi Arabia with only 8\% of total emissions. It was also one of the biggest beneficiaries of sukuks denominated in US dollars (19\% of total emissions worldwide in 2012) (Note 2).

In addition to developing activities of IBs, Malaysian supervisory authorities insisted on the promotion of risk management policies and on IBs and CBs detaining a sufficient level of capital. The Financial stability and payment systems report, published by the BNM in 2007, indicates that the five largest banking groups have seen an increase in capital since 2007 (Note 3). In addition, the beginning of 2008 was marked by the entry into force of the Basel II Accord requiring Malaysian banks to adopt the different approaches defined by the Basel Committee for Risk Assessment. The application of this device by IBs complies with the relevant recommendations of the IFSB.

In this paper, we intend to examine the changes undergone by the Malaysian banking system so as to study their influence on cost and revenue efficiency over the 2006 to 2012 period. In particular, we focus on the effect of change in market structure, regulatory capital and size. This paper is organized into five sections. The literature review and our hypotheses are presented in section 1. The methodology is presented in section 2. Section 3 describes the data. The results are presented and discussed in section 4 . The last section concludes the paper.

\section{Literature Review and Hypotheses}

\subsection{Literature Review}

Analysis of the determinants of efficiency is made by means of the following: risk, capital, size, and market competitiveness. The relationship with risk has led to different results. Gorton and Rosen (1995) explain the positive relationship between efficiency and risk by the hypothesis that rooted managers in an efficient bank tend to follow an expansionist strategy, which may appear excessively risky. Hughes et al. (1994) suggest that, under the assumption of risk aversion, managers are willing to give up part of their compensations in favour of risk reduction. Miller and Noulas (1997) notice that an increase in credit risk leads to an improvement in profit margin, leading subsequently to an enhancement of efficiency (Johnes et al., 2013). Among the studies that corroborate a positive relationship between efficiency and risk we mention those of Altunbas et al. (2007), Yener et al. (2007), Yong and Christos (2013) and Saeed and Izzeldin (2014). However, Kwan and Eisenbeis (1997) point to a positive relationship between inefficiency and risk taking. In addition, Barajas et al. (1999) assume that banks have to incur additional expenses so as to manage properly any increase in credit risk. The negative relationship between efficiency and risk is also supported by Berger and De Young (1997), Deelchand and Padgett (2009).

The relationship between efficiency and capital was considered in the analysis of the relationship between capital, risk and efficiency. Hughes and Moon (1995) highlighted the importance of introducing an efficiency independent variable in empirical models dealing with the relationship between risk and capital. Examining a sample of European banks between 1992 and 2000, Altunbas et al. (2007) found that the most efficient banks tend to take more risks, while the least efficient banks appear to hold higher levels of capital with lower levels of credit risk. The same result is obtained by Yener et al. (2007) on a sample of commercial banks, savings banks and cooperative banks in Europe. Examining a sample of 263 Japanese cooperative banks over the 2003 to 2006 period, Deelchand and Padgett (2009) modelled the relationship between risk, capital and cost efficiency. The results of this modelling show that inefficient banks operate with more capital while maintaining a high level of risk. Yong and Christos (2013) assessed the relationship between risk, capital and efficiency on a sample of 101 Chinese commercial banks between 2003 and 2009. The authors found that banks with higher liquidity levels present lower pure and technical efficiencies and higher capitalization. However, examining a sample of US banks, Kwan and Eisenbeis (1997) found a positive relationship between efficiency and capitalization, which implies that the best-managed banks have a higher capacity of capital accumulation.

Size is among the other variables used to study efficiency determinants. In this regard, several empirical evidences proved the existence of a positive relationship between efficiency and size in the banking industry (Bhattacharryya et al., 1997), Miller and Noulas (1996), Jackson and Fethi (2000), Chen et al. (2005), Abdul Majid et al. (2005), Drake et al. (2003) and Yong and Christos (2013). However, Deelchand and Padgett (2009) show that large banks hold less capital, take more risks and are less efficient. Jensen (1986) argues that at a certain level the positive relationship between size and efficiency can be reversed when managers' power and their rewards largely relate to company growth and size. 
The relationship between efficiency and market competitiveness has also aroused the interest of several authors. Berger and Mester (2003) found that competition conditions are likely to affect banking performance and efficiency. A negative relationship between concentration of an industry and efficiency is supported by Berger and Mester (1997) with the "quite life" theory (Note 4). The theory assumes the absence of incentives for efficiency when competition is low (high market concentration). Mean while, a positive relationship agrees with the "Information generating hypothesis" that supposes that a greater market power makes it easier to access information and thus contributes to improving banking efficiency. This finding is confirmed by Maudos and De Guevara (2007), Casu and Girardone (2009) and Koetter et al. (2011).

\subsection{The Hypotheses}

The literature review allowed us to formulate the four hypotheses presented in Table 1. These hypotheses represent the relationship between cost and revenue efficiency and risk, capital, size, and market structure.

Table 1. Hypotheses

\begin{tabular}{|c|c|c|c|}
\hline & Relationship & Expected sign & Studies \\
\hline H1 & Risk and efficiency & + & $\begin{array}{l}\text { Gorton and Rosen (1995), Hughes et al. (1994), Miller and Noulas } \\
\text { (1997), Altunbas et al. (2007), Yener et al. (2007), Yong and } \\
\text { Christos (2013), Johnes et al. (2013), Saeed and Izzeldin (2014). }\end{array}$ \\
\hline $\mathrm{H} 2$ & Capital and efficiency & - & $\begin{array}{l}\text { Altunbas et al. (2007), Yener et al. (2007), Deelchand and Padgett } \\
\text { (2009) Yong and Christos (2013). }\end{array}$ \\
\hline $\mathrm{H} 3$ & Size and efficiency & + & $\begin{array}{l}\text { Bhattacharryya et al, (1997), Miller and Noulas (1996), Jackson } \\
\text { and Fethi (2000), Chen et al. (2005), Abdul Majid et al. (2005), } \\
\text { Drake et al. (2003), Yong and Christos (2013). }\end{array}$ \\
\hline $\mathrm{H} 4$ & Market competitiveness and efficiency & + & $\begin{array}{l}\text { Berger and Hannan (1998), Delis and Tsionas (2009), Berger and } \\
\text { Mester (2003) and Coccorese and Pellecchia (2010). }\end{array}$ \\
\hline
\end{tabular}

\section{Methodology}

Before describing the methodology, it should be made clear that the calculation of cost efficiency scores is done through the meta-frontier cost function proposed by Battese et al. (2004) (Note 5). The estimation of this function requires solving the following optimization program:

$$
\operatorname{Min} L^{*} \equiv \sum_{t=1}^{T} \sum_{i=1}^{N}\left[\ln f\left(X_{i t}, \hat{\varphi}_{(r)}\right)-\ln f\left(X_{i t}, \varphi^{*}\right)\right], \mathrm{s} / \mathrm{c} \ln f\left(X_{i t}, \varphi^{*}\right) \leq \ln f\left(X_{i t}, \hat{\varphi}_{(r)}\right)
$$

Where, $f\left(X_{i t}, \hat{\varphi}_{(r)}\right)$ is the stochastic frontier cost function associated with each banking group $r ; r=1$ : Islamic banks group, $r=2$ : conventional banks group; $X_{i t}$ is the vector of inputs and outputs (three inputs and two outputs are considered); $i: 1, \ldots, N$ ( $\mathrm{N}$ is the total number of banks in the sample); $t: 2006, \ldots, 2012 ; \hat{\varphi}_{(r)}$ is the vector of the estimated parameters of group $r ; f\left(X_{i t}, \varphi^{*}\right)$ is the meta-frontier cost function that is defined as a global function having a mathematical form that includes all the deterministic elements of the stochastic cost functions developed individually; $\varphi^{*}$ is the vector of parameters to be estimated.

Regarding revenue efficiency scores, they are also calculated following the resolution of the following optimization program:

$$
\operatorname{Min} \mathrm{L}^{*} \equiv \sum_{t=1}^{T} \sum_{i=1}^{N}\left|\ln f\left(X_{i t}, \varphi^{*}\right)-\ln f\left(X_{i t}, \hat{\varphi}_{(r)}\right)\right|, \operatorname{s} / \mathrm{c} \ln f\left(X_{i t}, \hat{\varphi}_{(r)}\right) \leq \ln f\left(X_{i t}, \varphi^{*}\right)
$$

Where, $f\left(X_{i t}, \hat{\varphi}_{(r)}\right)$ is the stochastic frontier revenue function related to group $r$ and $f\left(X_{i t}, \varphi^{*}\right)$ is the meta-frontier revenue function.

The evolution of the annual average of cost and revenue efficiency scores of IBs and CBs, obtained after the resolution of the two functions (1) and (2) (Note 6), are shown respectively in the two figures (1) and (2). Figure (3) presents the big similarity between the evolution trend of interest revenues and profits divided by total assets and that of the annual average of revenue efficiency scores. 


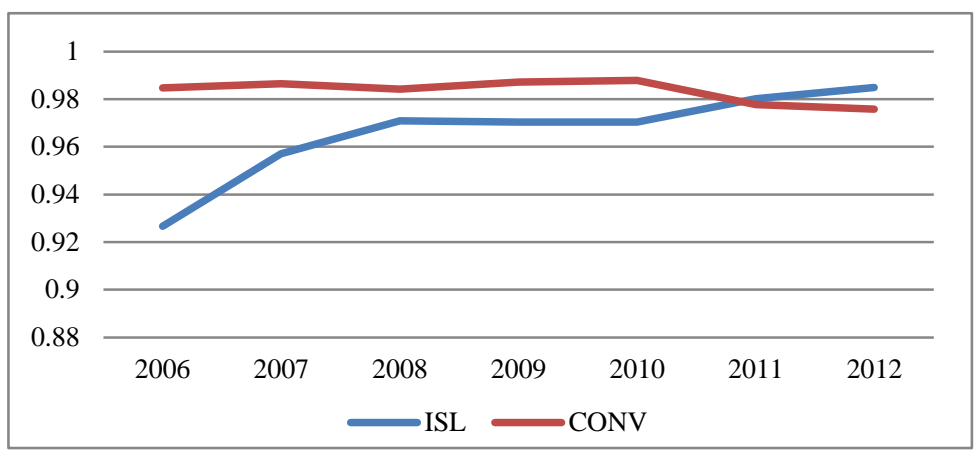

Figure 1. Annual average of cost efficiency scores measured by the MF

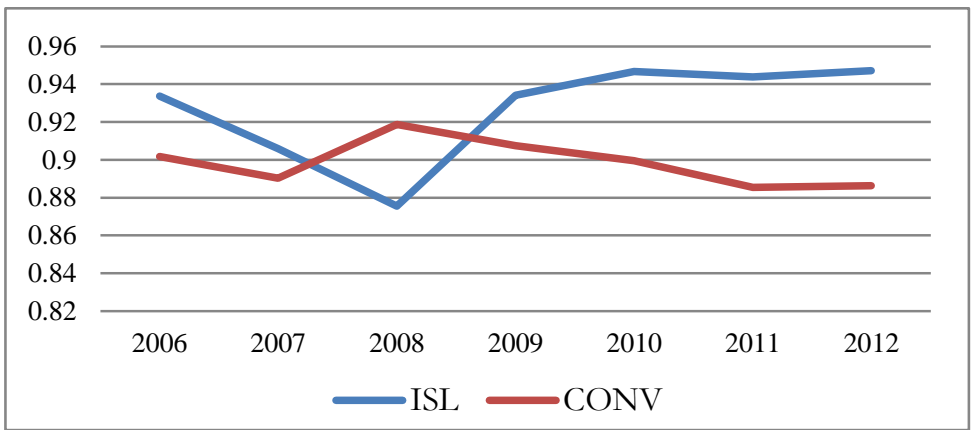

Figure 2. Annual average of revenue efficiency scores measured by the MF

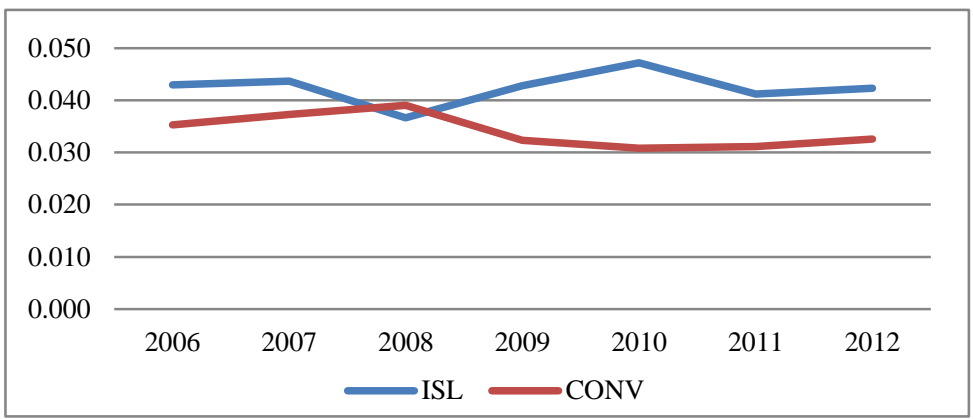

Figure 3. Interest or profit income/TA

Step 1: Calculating concentration ratios (C3 and C5), the Hirchmann Herfindahl index (HHI) and the Lerner index.

The issue of competition is of paramount importance in the banking sector because of its influence on financial stability (Demsetz et al., 1996), Hellmann et al. (2000), Allen and Gale (2004) and Jimenez et al. (2007) and on banking performance and efficiency (Berger \& Mester, 2003).

To calculate competitiveness of the Malaysian market, we will proceed in three stages. The first consists in computing concentration indices C3 (total market shares of the three main banks) and C5 (total market shares of the five main banks) using total loans, total assets and total deposits. These two ratios are calculated taking into account the existence of two banking groups that are representative respectively of IBs and CBs. The second stage consists in calculating the HHI that is obtained by summing the squared market shares of banks belonging to the IBs group (ISL), CBs group (CONV) or to a third group representative of all banks (ALL). In the third stage we calculate the Lerner index by the difference between price and marginal cost. This latter index indicates to what extent a company can increase its marginal price beyond its marginal cost (Berger et al., 2009). Its calculation requires the estimation of the parameters of the following translog cost function: 


$$
\begin{aligned}
\operatorname{LnCT}_{i t}= & \beta_{0}+\sum_{h=1}^{3} \alpha_{h} \operatorname{Ln}\left(P_{h i t}\right)+\sum_{k=1}^{2} \beta_{k} \operatorname{Ln}\left(Y_{k i t}\right)+\frac{1}{2} \sum_{h=1}^{3} \sum_{j=1}^{3} \alpha_{h j} \operatorname{Ln}\left(P_{h i t}\right) \operatorname{Ln}\left(P_{j i t}\right)+ \\
& \frac{1}{2} \sum_{j=1}^{2} \sum_{k=1}^{2} \beta_{j k} \operatorname{Ln}\left(Y_{j i t}\right) \operatorname{Ln}\left(Y_{k i t}\right)+\sum_{j=1}^{3} \sum_{k=1}^{2} \delta_{j k} \operatorname{Ln}\left(P_{j i t}\right) \operatorname{Ln}\left(Y_{k i t}\right)+\varepsilon_{i t}
\end{aligned}
$$

Where, $C T_{i t}$ is the total cost that includes finance charges and the amounts allocated to depositors in addition to personnel expenses, provision, amortization and other charges; $P_{\text {hit }}$ denotes the three used inputs: physical capital (K), financial capital (F) and labour (W); $Y_{k i t}$ denotesthe two considered outputs: total loans and total securities portfolio. This model is similar to the above mentioned meta-frontier cost function. For this reason, we will retain the parameters obtained following the resolution of model (1) to calculate marginal cost with the following formula:

$$
M C_{i t}=\left[\sum_{k=1}^{2} \beta_{k}+\sum_{j=1}^{3} \sum_{k=1}^{2} \delta_{j k} \operatorname{Ln}\left(P_{j i t}\right)+\sum_{j=1}^{2} \sum_{k=1}^{2} \beta_{j k} \operatorname{Ln}\left(Y_{j i t}\right)\right] \frac{C T_{i t}}{Y_{1 i t}+Y_{2 i t}}
$$

Where, $M C_{i t}$ is the cost of the last unit produced or marginal cost.

After calculating marginal cost, the Lerner index is determined as follows:

$$
\text { Lerner }_{i t}=\frac{P_{i t}-M C_{i t}}{P_{i t}}
$$

Where, $P_{i t}$ is the average price of banking products $\left(Y_{1 i t}, Y_{2 i t}\right)$.It is thus equal to the ratio of total revenues $\left(T R_{i t}\right.$ : Interest revenues (Note 7) as well as those originating from other operating activities) to total assets bearing those revenues $\left(Y_{1 i t}+Y_{2 i t}\right)$ of bank $i$ at time $t$, hence:

$$
P_{i t}=\frac{T R_{i t}}{Y_{1 i t}+Y_{2 i t}}
$$

2nd step: The study of the determinants of cost and revenue efficiency

Bearing in mind the four hypotheses to be tested, three sets of variables will be considered: bank-specific variables representing management quality, macroeconomic variables reflecting the influence of the economic environment and industry-specific variables. The selection of these variables will be carried out taking into account the multicollinearity problem that can cause unnecessarily large standard deviations, erroneous $t$-statistics (low or high) and parameters estimates of illogical signs. We will examine this issue in three stages. The first measures pair-wise correlation between the different variables. It is customary to consider that a correlation coefficient greater than 50\% indicates the presence of a multicollinearity problem. The second stage consists in calculating VIFs (Variance Inflation Factors) after regression of each independent variable on the others. The VIF statistic for each variable is $\left(1 /\left(1-\mathrm{R}^{2}\right)\right)$. There is a multicollinearity problem when the value of this statistic is greater than 10 and / or when the average of the VIFs is greater than 2 (Chatterjee et al., 2000). If these two conditions are met, all considered independent variables can be preserved. Calculating the indicators defined by Belsley et al. (1980), namely condition indexes and variance decomposition, will be the subject of the last stage.

3rd step: Presentation of the model to be estimated

After selecting the different independent variables, measuring efficiency determinants consists in estimating the following model:

$$
C E_{i t}\left(R E_{i t}\right)=\alpha+\beta X_{n, t}+\gamma M_{t}+u_{n}+\varepsilon_{n, t}
$$

Where, $n=1, \ldots, N$ represents the banks; $t: 1, \ldots . ., T$ represents time; $C E_{i t}\left(R E_{i t}\right):$ a dependent variable that represents in the first step cost efficiency and in the second revenue efficiency; $\alpha$ represents the non-random fixed effect to be estimated; $u_{n} \sim \operatorname{IID}\left(0, \sigma_{u}^{2}\right)$ is the random effect specific to each bank $(i)$ and is constant over time; $\varepsilon_{n, t} \sim \operatorname{IID}\left(0, \sigma_{\varepsilon}^{2}\right)$ represents the model's error or the unidentified random variations; $X_{n, t}$ is the vector of bank- and industry-specific variables; and $M_{t}$ is the vector of macroeconomic variables.

The choice of the method to be followed to estimate this model requires the study of heteroskedasticity and 
autocorrelation problems. Various tests will then be performed. The test of Bera et al. (2001) and that of Wooldridge (2002) to study errors autocorrelation, and the test of Breusch and Pagan (1979) and the likelihood ratio to study the heteroskedasticity problem. Some previous studies have applied the random effects model taking into account errors heteroskedasticity problem (Hoff, 2007), McDonald (2009) and Johnes et al. (2013), whereas others used a Tobit regression model (Casu \& Molyneux, 2003) and Sufian (2009).

\section{Data}

Our sample consists of 37 Malaysian commercial banks, 17 of which are IBs and 20 are CBs. The audited annual financial statements, which are available on the website of each of the banks in our sample, are the main sources of our data. In addition, data on the Malaysian financial system and macroeconomic indicators are extracted from the annual reports published by the BNM. The period of our study extends from 2006 to 2012. The total number of observations is 233: 103 observations for IBs and 130 for CBs. Table (A1) in the appendix summarizes the names of the banks, their nature (Islamic or conventional), affiliation (domestic or foreign), their creation date and the number of observations on each of them. It should be noted that all observations that might give biased results, because of their abnormal variability, were eliminated.

\section{Presentation and Analysis of Results}

Step1: Results of concentration indices (C3 and C5), the HH index and the Lerner index

The results in Table 2 indicate that a small number of banks are dominant in both IBs and CBs groups. Indeed, the C5 ratio calculated by total loans exceeded 70\% in CBs and 60\% in IBs. In addition, the calculation of both $\mathrm{C} 3$ and C5 ratios by total loans, total assets and total deposits reveals that the CBs group is more concentrated than IBs, except during the year 2006. This result is confirmed by the trend of the HHI of Islamic and conventional banks over the period 2006-2012 (Table 3).

Table 2. Calculation of $\mathrm{C} 3$ and $\mathrm{C} 5$ concentration ratios

\begin{tabular}{|c|c|c|c|c|c|c|c|c|c|c|c|c|}
\hline \multirow[t]{2}{*}{ Year } & \multicolumn{2}{|c|}{ Loans C3 } & \multicolumn{2}{|c|}{ Loans C5 } & \multicolumn{2}{|c|}{ Assets C3 } & \multicolumn{2}{|c|}{ Assets C5 } & \multicolumn{2}{|c|}{ Deposits C3 } & \multicolumn{2}{|c|}{ Deposits C5 } \\
\hline & ISL & CONV & ISL & $\mathrm{CONV}$ & ISL & CONV & ISL & $\mathrm{CONV}$ & ISL & $\mathrm{CONV}$ & ISL & CONV \\
\hline 2006 & 0,6235 & 0,5696 & 0,8806 & 0,7218 & 0,6017 & 0,5547 & 0,7942 & 0,6841 & 0,6251 & 0,5520 & 0,8178 & 0,6907 \\
\hline 2007 & 0,5024 & 0,5790 & 0,7119 & 0,7180 & 0,4783 & 0,5542 & 0,6751 & 0,6951 & 0,4938 & 0,5422 & 0,6809 & 0,6929 \\
\hline 2008 & 0,4422 & 0,5652 & 0,5887 & 0,7138 & 0,3952 & 0,5392 & 0,5716 & 0,6957 & 0,4107 & 0,5437 & 0,5890 & 0,7061 \\
\hline 2009 & 0,4870 & 0,5795 & 0,6638 & 0,7240 & 0,4521 & 0,5469 & 0,6394 & 0,6796 & 0,4661 & 0,5469 & 0,6536 & 0,7032 \\
\hline 2010 & 0,4850 & & & & & & & & & & 0,6264 & 0,6936 \\
\hline 2011 & 0,5181 & 0,5782 & 0,6731 & 0,7251 & 0,4595 & 0,5379 & 0,6414 & 0,6842 & 0,4686 & 0,5387 & 0,6521 & 0,7956 \\
\hline 2012 & 0,5035 & 0,5687 & 0,6658 & 0,7054 & 0,4938 & 0,6444 & 0,5418 & 0,7091 & 0,5067 & 0,5397 & 0,6553 & 0,7125 \\
\hline
\end{tabular}

Table 4 and Figure 4 summarize the evolution of the annual average of the Lerner index after being weighted by the market share associated with each bank belonging to the IBs group, CBs group or to all banks group. A higher average denotes a significant market power and subsequently poor competitiveness. Unlike the results of C3 and C5 and the HH index, the Lerner index's averages indicate that over the period 2007-2012, IBs had a more significant market power than CBs. This result supports the findings of Berger et al. (2004) and Beck et al. (2006) who suggest that concentration ratios as well as the HHI are poor indicators of competitiveness degree. The Lerner index will be therefore used to evaluate efficiency determinants.

Table 3.HHI by total loans, total assets and total deposits

\begin{tabular}{|c|c|c|c|c|c|c|c|c|c|}
\hline \multirow[t]{2}{*}{ Year } & \multicolumn{2}{|c|}{ Loans } & \multirow[b]{2}{*}{ ALL } & \multicolumn{2}{|c|}{ Assets } & \multirow[b]{2}{*}{ ALL } & \multicolumn{2}{|c|}{ Deposits } & \multirow[b]{2}{*}{ ALL } \\
\hline & ISL & CONV & & ISL & CONV & & ISL & $\mathrm{CONV}$ & \\
\hline 2006 & 0,188 & 0,1506 & 0,1104 & 0,1593 & 0,1367 & 0,0999 & 0,1702 & 0,1399 & 0,0996 \\
\hline 2007 & 0,1284 & 0,1523 & 0,1078 & 0,1227 & 0,1386 & 0,0972 & 0,127 & 0,1326 & 0,0923 \\
\hline 2008 & 0,1015 & 0,1453 & 0,0912 & 0,0870 & 0,1338 & 0,0833 & 0,0898 & 0,1371 & 0,0835 \\
\hline 2009 & 0,1135 & 0,1474 & 0,0905 & 0,1017 & 0,1357 & 0,0845 & 0,105 & 0,1362 & 0,0834 \\
\hline 2010 & 0,1113 & 0,1423 & 0,0847 & 0,0987 & 0,1322 & 0,0798 & 0,1011 & 0,1323 & 0,0782 \\
\hline 2011 & 0,126 & 0,1448 & 0,0856 & 0,1099 & 0,1325 & 0,0785 & 0,1119 & 0,1322 & 0,0763 \\
\hline 2012 & 0,1286 & 0,1453 & 0,0845 & 0,1198 & 0,1362 & 0,0799 & 0,1242 & 0,1345 & 0,0774 \\
\hline
\end{tabular}




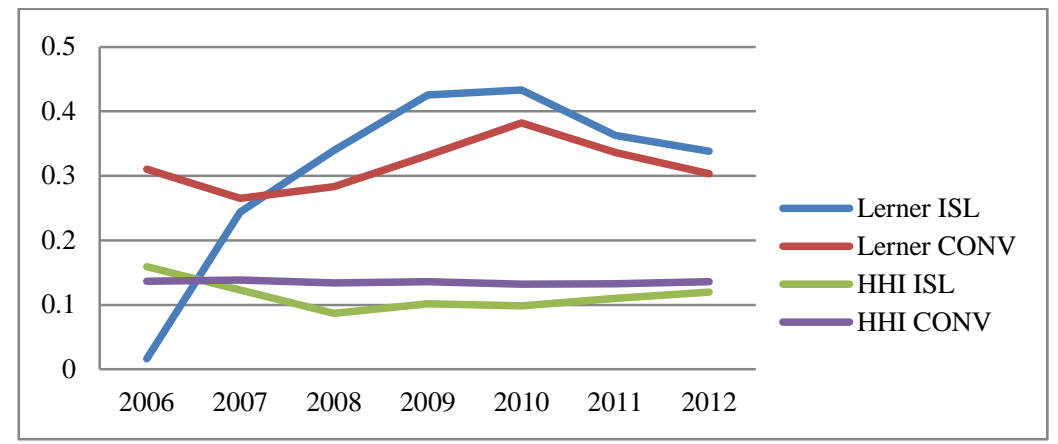

Figure 4. Annual average of the Lerner index and HHI over the period 2006-2012

Table 4. Annual average of the Lerner index over the period 2006-2012

\begin{tabular}{llll}
\hline & Islamic & Conventional & All \\
\hline 2006 & 0,01644408 & 0,31056506 & 0,11658335 \\
2007 & 0,2440702 & 0,26525966 & 0,25699926 \\
2008 & 0,33923568 & 0,28324371 & 0,28289016 \\
2009 & 0,42525585 & 0,33183998 & 0,3370014 \\
2010 & 0,43346136 & 0,38224193 & 0,37171997 \\
2011 & 0,3628454 & 0,33603762 & 0,33390762 \\
2012 & 0,33832483 & 0,3035825 & 0,30172982 \\
\hline
\end{tabular}

2nd step: Results of the selection of the different independent variables

After diagnosing multicollinearity profiles and eliminated all the variables that can cause a multicollinearity problem, fifteen variables are used to study efficiency determinants (Note 8). Table 5 summarizes all these variables.

Table 5. Description of variables used to analyze the determinants of efficiency

\begin{tabular}{|c|c|c|}
\hline Variables & & Definition \\
\hline \multicolumn{3}{|l|}{ Bank-specific variables } \\
\hline \multicolumn{3}{|l|}{ Profitability } \\
\hline Return on equity $R O E$ & $=$ & Pre-tax and zakat profit (loss) / Average shareholders' equity \\
\hline Non-financing income margin NFIM & $=$ & Non-finance income / Average total assets \\
\hline Return on deposit $R O D$ & $=$ & Pre-tax and zakat profit (loss)/ Average total customer deposits \\
\hline Gross NPF ratio GNPF & $=$ & Total non performing financing/Average gross loans and advances \\
\hline \multicolumn{3}{|l|}{ Liquidity } \\
\hline Financing to deposits ratio FTDR & $=$ & Net financing / Average total customer deposits \\
\hline Cash to deposits $C T D$ & $=$ & Cash / Average total customer deposits \\
\hline \multicolumn{3}{|l|}{ Capital } \\
\hline Risk weighted capital ratio $R W C R$ & $=$ & Eligible capital/Total risk-weighted assets \\
\hline Liabilities to shareholder capital LTSC & $=$ & Average total liabilities / Shareholder capital \\
\hline \multicolumn{3}{|l|}{ Efficiency } \\
\hline Interest expenses to deposits IETD & $=$ & Interest expenses/ Average total customer deposits \\
\hline Interest income to expenses IITE & $=$ & (Interest income-interest expenses) / Average loans and advances \\
\hline \multicolumn{3}{|l|}{ Others } \\
\hline Size Assets & $=$ & Total assets \\
\hline Islamic & $=$ & A binary variable to reflect whether or not the bank is classified as Islamic \\
\hline \multicolumn{3}{|l|}{ Industry specific variables } \\
\hline Lerner index & $=$ & Annual Lerner index \\
\hline \multicolumn{3}{|l|}{ Macroeconomics variables } \\
\hline GDP growth $G G D P$ & $=$ & Annual GDP growth rate \\
\hline National house price index NHPI & $=$ & Annual NHPI growth rate (in real terms) \\
\hline
\end{tabular}


The descriptive statistics of these variables, shown in Table 6, are calculated after setting three time intervals: before, during and after the subprime mortgage crisis. The average of the intermediation ratio FTDR indicate that total credits to total deposits of IBs followed an upward trend during and after the subprime crisis. CBs almost kept the same percentage during the same period. This result reflects the Malaysian system's resistance to the last financial crisis. This finding is confirmed by the downward trend of the averages of the GNPF ratio over the entire period 2006-2012. Furthermore, analysis of the average of RWCR shows that starting from the second period CBs decided to increase their risk weighted capital. The decision of IBs is different given that the average of this ratio decreased from 19,4\% to 16,2\% between the second and the third period (see also Figures 5a and 5b). The evolution trend of this ratio provides us then with the possibility to evaluate the effects of change in regulatory capital on efficiency. The difference between CBs and IBs is also reflected through the profitability indicators. Indeed, when the average of the ROE ratio of CBs recorded a decrease between the second and third period, that of IBs increased from $9,6 \%$ to $14,2 \%$.

3rd Step: Analysing the determinants of cost and revenue efficiency

The study of efficiency determinants begins with running specification tests whose results are shown in Table 7. The Lagrange multiplier test developed by Baltagi and Li (1990) for unbalanced panel data, originally devised by Breush and Pagan (1980) for balanced panel data, attests for the validity of the random effects model as p-value of each dependent variable is below 5\% (rejection of hypothesis $\mathrm{H}(0)$ ). However, Bera and Yoon (1993) show that in the presence of first-order autocorrelation, the Lagrange multiplier test developed by Baltagi and $\mathrm{Li}$ (1990) tends to reject the null hypothesis of the absence of random effects even if it is correct. For this reason, a modified Lagrange multiplier test was developed by Bera et al. (2001) for balanced and unbalanced panel data.

Table 6. Descriptive statistics of the independent variables

\begin{tabular}{|c|c|c|c|c|c|c|c|c|c|c|c|c|c|c|}
\hline & \multicolumn{6}{|c|}{ Conventional } & \multicolumn{6}{|c|}{ Islamic } & \multirow{2}{*}{\multicolumn{2}{|c|}{$\frac{\text { All }}{2006 / 12}$}} \\
\hline & \multicolumn{2}{|c|}{$2006 / 07$} & \multicolumn{2}{|c|}{$2008 / 09$} & \multicolumn{2}{|c|}{$2010 / 12$} & \multicolumn{2}{|c|}{$2006 / 07$} & \multicolumn{2}{|c|}{$2008 / 09$} & \multicolumn{2}{|c|}{$2010 / 12$} & & \\
\hline & Mean & SD & Mean & SD & Mean & SD & Mean & SD & Mean & SD & Mean & SD & Mean & SD \\
\hline ROE & 0,160 & 0,135 & 0,181 & 0,100 & 0,146 & 0,102 & $-0,184$ & 1,303 & 0,096 & 0,098 & 0,142 & 0,132 & 0,156 & 0,401 \\
\hline NFIM & 0,012 & 0,005 & 0,012 & 0,011 & 0,011 & 0,006 & 0,007 & 0,008 & 0,003 & 0,003 & 0,004 & 0,002 & 0,008 & 0,006 \\
\hline ROD & 0,037 & 0,042 & 0,032 & 0,038 & 0,021 & 0,035 & $-0,100$ & 0,454 & 0,010 & 0,013 & 0,011 & 0,029 & 0,226 & 0,139 \\
\hline GNPF & 0,051 & 0,023 & 0,030 & 0,024 & 0,022 & 0,022 & 0,063 & 0,066 & 0,036 & 0,041 & 0,024 & 0,041 & 0,034 & 0,036 \\
\hline FTDR & 0,882 & 0,755 & 0,824 & 0,560 & 0,819 & 0,676 & 0,668 & 0,374 & 0,836 & 0,339 & 0,889 & 0,240 & 0,833 & 0,543 \\
\hline CTD & 0,724 & 0,915 & 0,505 & 0,645 & 0,888 & 1,619 & 0,660 & 0,560 & 0,462 & 0,297 & 0,346 & 0,262 & 0,556 & 0,982 \\
\hline RWCR & 0,239 & 0,260 & 0,171 & 0,065 & 0,293 & 0,445 & 0,344 & 0,577 & 0,194 & 0,161 & 0,162 & 0,066 & 0,196 & 0,313 \\
\hline LTSC & 75,125 & 98,81 & 80,433 & 108,1 & 84,885 & 126,1 & 15,125 & 9,457 & 48,878 & 65,46 & 76,499 & 133,6 & 69,851 & 108,98 \\
\hline IETD & 0,063 & 0,058 & 0,041 & 0,027 & 0,032 & 0,018 & 0,033 & 0,017 & 0,028 & 0,013 & 0,032 & 0,008 & 0,143 & 0,030 \\
\hline IITE & 0,093 & 0,190 & 0,059 & 0,061 & 0,129 & 0,357 & 0,088 & 0,143 & 0,046 & 0,019 & 0,046 & 0,015 & 0,081 & 0,205 \\
\hline Assets & 44507 & 55076 & 50066 & 60711 & 56915 & 76141 & 7361 & 4858 & 11232 & 8704 & 18601 & 18212 & 35560 & 54564 \\
\hline GGDP & 0,059 & 0,003 & 0,017 & 0,032 & 0,059 & 0,008 & 0,060 & 0,003 & 0,018 & 0,032 & 0,060 & 0,008 & 0,047 & 0,027 \\
\hline NHPI & 0,007 & 0,024 & 0,001 & 0,008 & 0,072 & 0,018 & 0,010 & 0,025 & 0,000 & 0,008 & 0,071 & 0,021 & 0,035 & 0,039 \\
\hline
\end{tabular}

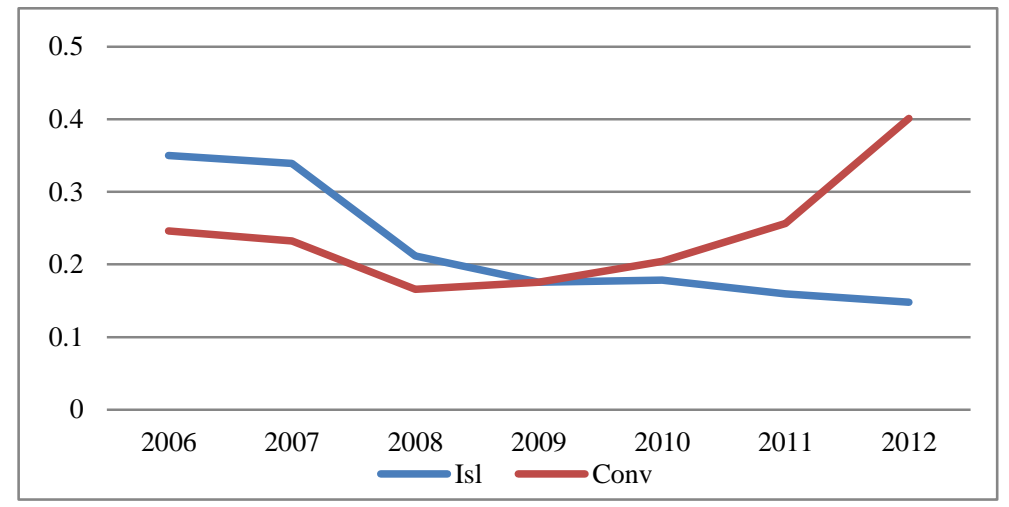

Figure 5a. The evolution of the average RWCR 


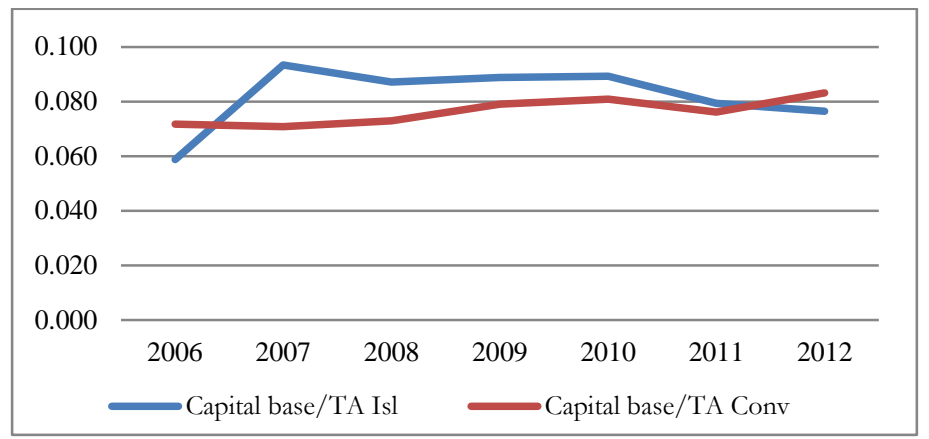

Figure $5 \mathrm{~b}$. The evolution of capital base

The results, reported in Table 6, show that the test of random effects $(\mathrm{LM}(\operatorname{Var}(\mathrm{u})=0)$ ) and the joint test of Baltagi and $\mathrm{Li}$ (1991) for serial correlation and random effects reject the null hypothesis which indicates the absence of random effects. However, the results of the modified version of the Lagrange multiplier test (ALM $(\operatorname{Var}(\mathrm{u})=0)$ ) developed by Bera et al. (2001) fail to reject the null hypothesis and prove that rejecting the null hypothesis of the joint test is mainly the result of the presence of a serial correlation problem. This finding is confirmed by Wooldridge (2002) whose null hypothesis, which was rejected, assumes the absence of first-order autocorrelation. As for the heteroskedasticity problem, the results of the Breusch and Pagan (1979) test and the Likelihhod Ratio test, whose null hypothesis is in favour of an errors homoskedasticity, show that H0 hypothesis is widely rejected, which proves the presence of a heteroskedasticity problem. Among the solutions proposed to solve these two problems (first-order autocorrelation and heteroskedasticity), we opted for the FGLS method developed by Parks (1967). Table (8) provides the estimation results of the two efficiency models through this method.

Table 7. Model specification tests

\begin{tabular}{|c|c|c|c|c|c|}
\hline & \multicolumn{2}{|l|}{$\mathrm{CE}$} & \multicolumn{3}{|l|}{ RE } \\
\hline \multicolumn{6}{|c|}{ 1-Lagrange multiplier test: CE (RE) [ID,T] = XB + U[ID $]+$ E[ID,T $] /$ TEST: VAR (U) = 0 } \\
\hline chibar2(01) & \multicolumn{2}{|c|}{3,64} & \multicolumn{3}{|c|}{26,50} \\
\hline Prob> chibar2 & \multicolumn{2}{|c|}{0,0282} & \multicolumn{3}{|c|}{0,0205} \\
\hline \multicolumn{6}{|c|}{ 2-Random effects and order-one serial correlation test } \\
\hline \multicolumn{6}{|c|}{$\mathrm{CE}(\mathrm{RE})[\mathrm{id}, \mathrm{t}]=\mathrm{Xb}+\mathrm{u}[\mathrm{id}]+\mathrm{v}[\mathrm{id}, \mathrm{t}] / \quad \mathrm{v}[\mathrm{id}, \mathrm{t}]=$ lambda $\mathrm{v}[\mathrm{id},(\mathrm{t}-1)]+\mathrm{e}[\mathrm{id}, \mathrm{t}]$} \\
\hline \multicolumn{6}{|l|}{ Random Effects, Two Sided: } \\
\hline $\mathrm{LM}(\operatorname{Var}(\mathrm{u})=0)$ & $=3,64$ & $\operatorname{Pr}>\operatorname{chi} 2(1)=0,0563$ & $=26,50$ & $\operatorname{Pr}>\operatorname{chi} 2(1)=$ & 0,0410 \\
\hline $\operatorname{ALM}(\operatorname{Var}(\mathrm{u})=0)$ & $=0,77$ & $\operatorname{Pr}>\operatorname{chi} 2(1)=0,3799$ & $=0,02$ & $\operatorname{Pr}>\operatorname{chi} 2(1)=$ & 0,8880 \\
\hline \multicolumn{6}{|l|}{ Random Effects, One Sided: } \\
\hline $\mathrm{LM}(\operatorname{Var}(\mathrm{u})=0)$ & $=1,91$ & $\operatorname{Pr}>\mathrm{N}(0,1)=0,0282$ & $=5,15$ & $\operatorname{Pr}>\mathrm{N}(0,1) \quad=$ & 0,0000 \\
\hline $\operatorname{ALM}(\operatorname{Var}(\mathrm{u})=0)$ & $=-0,88$ & $\operatorname{Pr}>\mathrm{N}(0,1)=0,8100$ & $=-0,14$ & $\operatorname{Pr}>\mathrm{N}(0,1) \quad=$ & 0,5560 \\
\hline \multicolumn{6}{|l|}{ Serial Correlation: } \\
\hline LM (lambda=0) & $=22,72$ & $\operatorname{Pr}>\operatorname{chi} 2(1)=0,0000$ & $=90,40$ & $\operatorname{Pr}>\operatorname{chi} 2(1)=$ & 0,0000 \\
\hline ALM $($ lambda=0) & $=19,84$ & $\operatorname{Pr}>\operatorname{chi} 2(1)=0,0000$ & $=63,91$ & $\operatorname{Pr}>\operatorname{chi} 2(1)=$ & 0,0000 \\
\hline \multicolumn{6}{|l|}{ Joint Test: } \\
\hline $\mathrm{LM}(\operatorname{Var}(\mathrm{u})=0, \operatorname{lambda}=0)$ & \multirow{2}{*}{$\begin{array}{l}=23,49 \\
\text { panel d }\end{array}$} & $\operatorname{Pr}>\operatorname{chi} 2(2)=0,0000$ & $=90,42$ & $\operatorname{Pr}>\operatorname{chi} 2(2)=$ & 0,0000 \\
\hline \multicolumn{5}{|c|}{ 3- Wooldridge test for autocorrelation in panel data, H0: No first order autocorrelation } & \\
\hline $\mathrm{F}(1,35)$ & \multicolumn{2}{|c|}{7,758} & \multicolumn{3}{|c|}{$=49,124$} \\
\hline Prob> F & \multicolumn{2}{|c|}{0,0086} & \multicolumn{3}{|c|}{$=0,0387$} \\
\hline \multicolumn{6}{|c|}{ 4-Breusch-Pagan / Cook-Weisberg test for heteroskedasticity, Ho: Constant variance } \\
\hline $\operatorname{chi} 2(1)$ & $=$ & & $=$ & & \\
\hline Prob> chi2 & $=0,0$ & & 0,0 & & \\
\hline 5- Likelihood-ratio test, & is homo & lastic & & & \\
\hline LR chi2(37) & $=$ & & $=$ & & \\
\hline Prob> chi 2 & $=$ & & $=$ & & \\
\hline
\end{tabular}

The results show a negative and a statistically significant relationship at the $1 \%$ level between the "Islamic" 
variable and cost efficiency, which confirms the hypothesis indicating that Islamic banking activity is known by higher personnel and administrative costs than that of CBs. Estimating the second model, we come to reject this hypothesis given that the relationship between revenue efficiency and the "Islamic" variable becomes positive and statistically significant at the $1 \%$ level, which is partially explained by the high profit and income originating from operations carried out by IBs compared to the interest-based revenues of CBs (see Figure 3).

Table 8. Estimation of the two efficiency models by the FGLS method

\begin{tabular}{|c|c|c|c|c|c|c|}
\hline & \multicolumn{3}{|c|}{$C E$} & \multicolumn{3}{|c|}{$R E$} \\
\hline & Coef. & Std. Err. & $\mathrm{P}>|\mathrm{z}|$ & Coef. & Std. Err. & $\mathrm{P}>|\mathrm{z}|$ \\
\hline$R O E$ & $-0,0030627$ & 0,0012885 & 0,017 & 0,0108006 & 0,0057536 & 0,060 \\
\hline NFIM & $-1,233642$ & 0,0989838 & 0,000 & 3,42482 & 0,4387366 & 0,000 \\
\hline$R O D$ & 0,2220435 & 0,0058081 & 0,000 & $-0,0423965$ & 0,0273205 & 0,121 \\
\hline IETD & $-0,0342347$ & 0,0304419 & 0,261 & $-0,2693107$ & 0,141069 & 0,056 \\
\hline IITE & $-0,0006908$ & 0,0036773 & 0,851 & 0,0184327 & 0,0204068 & 0,366 \\
\hline$G N P F$ & 0,0204916 & 0,0204916 & 0,000 & 0,0441019 & 0,0565382 & 0,435 \\
\hline$F T D$ & $-0,0025709$ & 0,0018861 & 0,173 & 0,0062755 & 0,0073635 & 0,394 \\
\hline$C T D$ & 0,0016454 & 0,000871 & 0,059 & $-0,0088897$ & 0,0033111 & 0,007 \\
\hline$R W C R$ & $-0,0251374$ & 0,0019555 & 0,000 & $-0,0426305$ & 0,006314 & 0,000 \\
\hline LTSC & $6,14 \mathrm{e}-06$ & $6,14 \mathrm{e}-06$ & 0,002 & 0,0000203 & 0,000019 & 0,285 \\
\hline Islamic & $-0,018867$ & 0,0022155 & 0,000 & 0,0566205 & 0,0068511 & 0,000 \\
\hline ASSETS & 7,91e-08 & $1,93 \mathrm{e}-08$ & 0,000 & $1,75 \mathrm{e}-07$ & $4,24 \mathrm{e}-08$ & 0,000 \\
\hline Lerner & $-0,0002178$ & 0,0001402 & 0,120 & 0,000753 & 0,0001663 & 0,000 \\
\hline$G G D P$ & $-0,0058414$ & 0,0094104 & 0,535 & 0,0249665 & 0,0459758 & 0,587 \\
\hline NHPI & 0,0251452 & 0,0114218 & 0,028 & $-0,0536915$ & 0,0448147 & 0,231 \\
\hline Cons & 0,9946601 & 0,0026838 & 0,000 & 0,8695501 & 0,0111616 & 0,000 \\
\hline \multicolumn{2}{|c|}{ No. of observations } & & 233 & & & 233 \\
\hline \multicolumn{2}{|c|}{ No. of banks } & & 37 & & & 37 \\
\hline \multicolumn{2}{|c|}{ Wald $X_{15}^{2}$} & & 4984.58 & & & 559.27 \\
\hline \multicolumn{2}{|c|}{ Prob $>X_{15}^{2}$} & & 0,0000 & & & 0,0000 \\
\hline
\end{tabular}

The GNPF variable (credit risk) presents a positive and a statistically significant coefficient at the $1 \%$ level in the first model which is consistent with the findings of Miller and Noulas (1997), Gorton and Rosen (1995), Altunbas et al. (2007), Yener et al. (2007), Yong and Christos (2013) and Saeed and Izzeldin (2014). Both CTD and FTDR variables reveal that an increase in liquidity improves cost efficiency (Note 9) and deteriorates revenue efficiency. The positive effect of the intermediation activity (as indicated by FTDR ratio) on revenue efficiency is also confirmed by the positive sign of the IITE ratio. These results partially support hypothesis (H1) which supposes a positive relationship between efficiency and risk.

The negative and statistically significant coefficient of RWCR implies that an increase in capital decreases efficiency, confirming hypothesis (H2). The nature of this relationship can be explained by the proposals of Jensen (1986), who highlighted the problem of "free cash flow" arising from the way available flows are allocated after funding all profitable projects. The negative relationship between efficiency and capital is also validated by Deelchand and Padgett (2009) and Altunbas et al. (2007) who prove that inefficient banks seem to operate with more capital. In this regard Jensen proposes the recourse to debt as a tool to control manager's behaviour. This proposal explains the positive sign of the LTSC ratio (total liabilities divided by total equity). Indeed, with the issuance of new debts to finance new projects, Jensen explains that managers are at risk of losing their jobs in case the company does not comply with its' commitments to its creditors. It should be noted that the LTSC coefficient is statistically significant at the $1 \%$ level.

A negative and a statistically significant relationship was observed between the two profitability ratios, ROE and NFIM, and cost efficiency. The negative relationship between financial return ROE and cost efficiency is consistent with the results of Kablan and Yousfi (2011) on a sample of IBs and CBs. However, Table (8) shows a positive relationship between these two ratios and revenue efficiency scores. Such contradictory effects of profitability reflect the burden of personnel expenses and other overheads and expenditures incurred by the most profitable banks in order to achieve better revenues. It should be mentioned that throughout the period of our study, Malaysian banks have incurred huge personnel and administrative costs to improve their capacity of risk 
and cost management. In addition, the effect of operating expenses on cost efficiency can be observed through the positive sign of the ROD ratio. Indeed, a strong negative correlation (-0.9428) is detected between this ratio and the COTAA ratio (Cost over total average assets). An increase in the ROD ratio then comes in parallel along a decrease in the COTAA ratio and afterwards results in improvement in cost efficiency.

Regarding the size variable, its impact on cost and revenue efficiency is positive and statistically significant at the $1 \%$ level, which corroborates hypothesis (H3). However, Jensen (1986) states that starting from a certain level, this relationship can be reversed as soon as the power of managers and their compensation largely depend on company growth and size. This latter finding has prompted us to examine change in cost and revenue efficiency across different sizes. To this end, three sizes were identified: small banks (between 1 million RM and 20 millions RM), medium-sized banks (between 20 million RM and 50 million RM) and large banks (more than 50 million RM).

Table 9. Cost and revenue efficiency according to each size

\begin{tabular}{|c|c|c|c|c|c|c|}
\hline \multirow[b]{2}{*}{ Size } & \multicolumn{3}{|c|}{$C E$} & \multicolumn{3}{|c|}{$R E$} \\
\hline & Mean & $\mathrm{SD}$ & $p$-value & Mean & $\mathrm{SD}$ & $p$-value \\
\hline Small & 0,9713102 & 0,0044613 & & 0,8999639 & 0,0065259 & \\
\hline Medium & 0,9841449 & 0,0019537 & 0,0568 & 0,9344156 & 0,0063957 & 0,0027 \\
\hline Large & 0,9887748 & 0,0016257 & 0,0366 & 0,9143073 & 0,0061245 & 0,0153 \\
\hline
\end{tabular}

Estimating cost and revenue efficiency across these different sizes shows mixed results (Table 9). Indeed, whereas cost efficiency shows a statistically significant increase as we progress from small banks to large banks, the difference between revenue efficiency of large banks and that of small ones remain negative and statistically significant at the 5\% level. These results support the findings of Jensen (1986) and confirm that some Malaysian banks have reached their optimal size.

Table 10. Cost and revenue Efficiency according to size and banking category

\begin{tabular}{|c|c|c|c|c|c|c|}
\hline \multirow[b]{2}{*}{ Size } & \multicolumn{3}{|c|}{$C E$} & \multicolumn{3}{|c|}{$R E$} \\
\hline & Mean ISL & Mean CONV & p-value & Mean ISL & Mean CONV & $p$-value \\
\hline Small & 0,9624455 & 0,9838545 & 0,0087 & 0,9176829 & 0,8748899 & 0,0005 \\
\hline Medium & 0,9841621 & 0,9841294 & 0,5033 & 0,9514582 & 0,9189961 & 0,0047 \\
\hline Large & 0,9859016 & 0,9890314 & 0,3008 & 0,9608556 & 0,9101512 & 0,0109 \\
\hline
\end{tabular}

Table 10 shows that a decrease in revenue efficiency for large banks is explained by a low average of efficiency scores obtained by CBs. In terms of cost efficiency, small size IBs seem to be less efficient than CBs. The difference between the two averages is statistically significant at the $1 \%$ level. This difference becomes insignificant for medium and large banks. This result reaffirms the positive effect of size on efficiency and points to one of the most important factors behind the weakness of the cost efficiency of IBs between 2006 and 2010. As for revenue efficiency, all obtained averages support the superiority of IBs over CBs.

Regarding the three exogenous variables, only the NHPI variable is statistically significant in the first model. This result reflects the importance of the measures undertaken by the Malaysian banks to protect themselves against risks arising from an excessive price increase in the real estate market. In the second model, the Lerner variable coefficient is positive and statistically significant which reflects a negative relationship between competitiveness and revenue efficiency, hence the rejection of hypothesis (4). The insignificant effect of economic development (GGDP) is also supported by Saeed and Izzeldin (2014) (Note 10).

\section{Conclusion}

The main aim of this paper is to study the determinants of cost and revenue efficiency in the Malaysian banking sector known by a coexistence of IBs and CBs. The calculation of competitiveness degree for this sector was the subject of the first step. Three types of indexes are calculated: the two concentration indexes $\mathrm{C} 3$ and $\mathrm{C} 5$, the $\mathrm{HH}$ index and the Lerner index. The results obtained from the $\mathrm{C} 3$ and $\mathrm{C} 5$ concentration indexes and the HH index indicate that the CBs group is generally more concentrated than IBs. The Lerner index present different results because it indicates that in the period 2007-2012 CBs have a greater competitiveness degree than IBs. These different results support the findings of Berger et al. (2004) and Beck et al. (2006) who found that concentration 
ratios and the $\mathrm{HH}$ index are poor indicators of competitiveness degree. In addition to the Lerner index (industry-specific variable), the second step allowed for the identification of two sets of variables: bank-specific variables (profitability, liquidity, capital, efficiency and size), and macroeconomic variables (GDP growth and National house price index). The last step involves the use of the FGLS method to estimate the coefficients of the efficiency models. This step provided supervision authorities and especially managers with useful information on ways to improve performance. The obtained results show that the Islamic variable presents a negative and a statistically significant relationship with cost efficiency and a positive one with revenue efficiency. This result can be explained by the fact that personnel expenses and administrative costs of IBs are more important than higher profit and commission income. The GNPF variable reveals a positive relationship between cost efficiency and credit risk while the two liquidity ratios (CTD and FTD) show that any increase in liquidity leads to an improvement in cost efficiency at the expense of revenue efficiency. These latter results partially support hypothesis $\mathrm{H} 1$ which supposes a positive relationship between efficiency and risk. As for hypothesis $\mathrm{H} 2$, it is confirmed since the results of the two efficiency models support the presence of a negative relationship between regulatory capital and efficiency. It should be noted that the regulatory capital of IBs, until the end of 2010, was higher than that of CBs. As for the size variable, the results are consistent with our expectations, since any increase in size leads to an increase in efficiency. The study of this relationship, while taking into account bank category, shows that the difference between Islamic and conventional banks in terms of cost efficiency becomes insignificant in both medium and large banks. Moreover, the results indicate that revenue efficiency of CBs decreased starting from a certain size level. This result confirms Jensen's proposal which supposes the existence of an optimal size. As for the influence of competitiveness, a positive and a statistically significant relationship was found between the Lerner variable and revenue efficiency, hence the rejection of hypothesis $\mathrm{H} 4$.

\section{References}

Abdul-Majid, M., Mohammed Nor, N. G., \& Said, F. F. (2005). Efficiency of Islamic banks in Malaysia. In M. Iqbal, \& A. Ahmad (Eds.), Islamic Finance and Economic Development. New York: Palgrave Macmillan.

Allen, F., \& Gale, D. (2004). Competition and financial stability. Journal of Money, Credit and Banking, 36(3), 453-480.

Altunbas, Y., Carbo, S., Gardener, E. P. M., \& Molyneux, P. (2007). Examining the relationships between capital, risk and efficiency in European banking. European Financial Management, 13, 49-70. http://dx.doi.org/10.1111/j.1468-036x.2006.00285.x

Baltagi, B., \& Li, Q. (1990). A Lagrange multiplier test for the error components model with incomplete panels. Econometric Reviews, 9, 103-107. http://dx.doi.org/10.1080/07474939008800180

Barajas, A., Steiner, R., \& Salazar, N. (1999). Interest spreads in banking in Colombia, 1974-96. IMF Staff Papers 46, 196.

Battese, G. E. D. S., Rao, P., \& O’Donnell, C. J. (2004). A Metafrontier Production Function for Estimation of Technical Efficiencies and Technology Gaps for Firms Operating Under Different Technologies. Journal of Productivity Analysis, 21, 91-103. http://dx.doi.org/10.1023/b:prod.0000012454.06094.29

Beck, T., Demirguc-Kunt, A., \& Levine, R. (2006). Bank concentration, competition, and crises: First results. Journal of Banking and Finance, 30, 1581-1603. http://dx.doi.org/10.1016/j.jbankfin.2005.05.010

Belsley, D., Kuh, A. E., \& Welsch, R. E. (1980). Regression diagnostics: Identifying influential data and sources of collinearity. New York: John Wiley \& Sons.

Bera, A., \& Yoon, M. (1993). Specification testing with locally misspecified alternatives. Econometric Theory, 9 , 649-658. http://dx.doi.org/10.1017/s0266466600008021

Bera, A., Sosa-Escudero, W., \& Yoon, M. (2001). Tests for the error component model in the presence of local misspecification. Journal of Econometrics, 101, 1-23. http://dx.doi.org/10.1016/s0304-4076(00)00071-3

Berger, A. N., \& DeYoung, R. (1997). Problem Loans and Cost Efficiency in Commercial Banks. Journal of Banking and Finance, 21, 849-870. http://dx.doi.org/10.2139/ssrn.2277

Berger, A. N., \& Hannan, T. (1998). The efficiency cost of market power in the banking industry: A test of the "quiet life" and related hypotheses. The Review of Economics and Statistics, 80(3), 454-465. http://dx.doi.org/10.1162/003465398557555

Berger, A. N., Demirguc-Kunt, A., Levine, R., \& Haubrich, J. (2004). Bank concentration and competition: An evolution in the making. Journal of Money, Credit and Banking, 36, 433-451. http://dx.doi.org/10.1353/mcb.2004.0040 
Berger, A. N., Klapper, L. F., \& Turk Ariss, R. (2009). Bank competition and financial stability. Journal of Financial Services Research, 35, 99-118. http://dx.doi.org/10.1596/1813-9450-4696

Berger, A., N., \& Mester, L. J. (1997). Inside the black box: What explains differences in the efficiencies of financial institutions. Journal of Banking and Finance, 21, 895-947. http://dx.doi.org/10.2139/ssrn.138159

Berger, A., N., \& Mester, L. J. (2003). Explaining the dramatic changes in performance of U.S. banks: Technological change, deregulation, and dynamics changes in competition. Journal of Financial Intermediation, 12, 57-95. http://dx.doi.org/10.2139/ssrn.283013

Bhattacharyya, A., Lovell, C. A. K., \& Sahay, P. (1997). The impact of liberalization on the productive efficiency of Indian commercial banks. European Journal of Operational Research, 98, 332-345. http://dx.doi.org/10.1016/s0377-2217(96)00351-7

Breusch, T. S., \& Pagan, A. R. (1979). A simple test for heteroscedasticity and random coefficient variation. Econometrica. The Econometric Society, 47(5), 1287-1294. http://dx.doi.org/10.2307/1911963

Breusch, T. S., \& Pagan, A. R. (1980). The Lagrange Multiplier Test and Its Applications to Model Specification in Econometrics. Review of Economic Studies, 47(1), 239-53. http://dx.doi.org/10.2307/2297111

Casu, B., \& Girardone, C. (2009). Testing the relationship between competition and efficiency in banking: A panel data analysis. Economics Letters, 105, 134-137. http://dx.doi.org/10.1016/j.econlet.2009.06.018

Casu, B., \& Molyneux, P. (2003). A comparative study of efficiency in European banking. Applied Economics 35(17), 1865-1876. http://dx.doi.org/10.1080/0003684032000158109

Chatterjee, S., Hadi, A., \& Price, B. (2000). Regression analysis by example. John Wiley \& Sons. http://dx.doi.org/10.2307/2669806

Chen, X., Skully, M., \& Brown, K. (2005). Banking efficiency in China: Application of DEA to pre-and post-deregulation eras 1993-2000. China Economic Review, 16, 229-245. http://dx.doi.org/10.1016/j.chieco.2005.02.001

Coccorese, P., \& Pellecchia, A. (2010). Testing the 'quiet life' hypothesis in the Italian banking industry. Economic Notes, 39(3), 173-202. http://dx.doi.org/10.1111/j.1468-0300.2011.00227.x

Deelchand, T., \& Padget, C. (2009). The Relationship between Risk, Capital and Efficiency: Evidence from Japanese Cooperative Banks. ICMA Discussion Paper in Finance, DP 2009-12. http://dx.doi.org/10.2139/ssrn.1525423

Delis, M., \& Tsionas, E. (2009). The joint estimation of bank-level market power and efficiency. Journal of Banking \& Finance, 33(10), 1842-1850. http://dx.doi.org/10.1016/j.jbankfin.2009.04.006

Demsetz, R., Saidenberg, M. R., \& Strahan, P. E. (1996). Banks with Something to Lose: The Disciplinary Role of Franchise Value. Economic Policy Review, 2, 1-14. http://dx.doi.org/10.2139/ssrn.1028769

Drake, L., \& Hall, M. J. B. (2003). Efficiency in Japanese banking: An empirical analysis. Journal of Banking and Finance, 27, 891-917. http://dx.doi.org/10.1016/s0378-4266(02)00240-6

Ghroubi, M., \& Abaoub, E. (2016). A meta-frontier function for the estimation of Islamic and Conventional Banks' cost and revenue efficiency: The case of Malaysia from 2006 to 2012. International Journal of Business and Management, 11(5), 254-270. http://dx.doi.org/10.5539/ijbm.v11n5p254

Gorton, G., \& Rosen, R. (1995). Corporate control, portfolio choice and the decline of banking. Journal of Finance, 50(5), 1377-1420. http://dx.doi.org/10.3386/w4247

Hellmann, T. F., Murdock, K., \& Stiglitz, J. (2000). Liberalization, moral hazard in banking and prudential regulation: Are capital requirements enough? American Economic Review, 90, 147-165. http://dx.doi.org/10.1257/aer.90.1.147

Hoff, A. (2007). Second stage DEA: Comparison of approaches for modeling the DEA score. European Journal of Operational Research, 181(1), 425-435. http://dx.doi.org/10.1016/j.ejor.2006.05.019

Hughes, J. P, \& Moon, C. (1995). Measuring bank efficiency when managers trade return for reduced risk. Department of Economics Rutgers University, Working Paper.

Hughes, J. P., Lang, W., Mester, L. J., \& Moon, C. G. (1994). Recovering Technologies That Account for Generalized Managerial Preferences: An Application to Non-Risk-Neutral Banks. Department of Economics, Rutgers University, 1994. 
Jackson, P. M., \& Fethi, M. D. (2000). Evaluating the technical efficiency of Turkish commercial banks: An application of DEA and Tobit analysis. University of Leicester Working paper.

Jensen, M. C. (1986). Agency costs of free cash flow, corporate finance and takeovers. AEA (American Economic Association) Papers and Proceedings, 76(2), 323-329. http://dx.doi.org/10.2139/ssrn.99580

Jimenez, G., Lopez, J., \& Saurina, J. (2007). How does competition impact bank risk taking? Working Paper: Banco de Espana. http://dx.doi.org/10.2139/ssrn.1582331

Johnes, J., Izzeldin, M., \& Pappas, V. (2013). A comparison of performance of Islamic and conventional banks 2004 to 2009. Journal of Economic Behavior and Organization. http://dx.doi.org/10.2139/ssrn.2071615

Kablan, S., \& Yousfi, O. (2011). Efficiency of Islamic and conventional banks in countries with Islamic banking. MPRA Paper No. 32951.

Koetter, M., Kolari, J., \& Spierdijk, L. (2011). Enjoying the quiet life under deregulation? Evidence from adjusted lerner indices for us banks. The Review of Economics and Statistics. http://dx.doi.org/10.2139/ssrn.1996806

Kwan, S., \& Eisenbeis, R. A. (1997). Bank risk, capitalization, and operating efficiency. Journal of Financial Services Research, 12(2-3), 117-131.

Maudos, J., \& De Guevara, J. (2007). The cost of market power in banking: Social welfare loss vs. cost $\begin{array}{lllll}\text { inefficiency. Journal of Banking \& } & \text { Finance, } 31(7),\end{array}$ http://dx.doi.org/10.1016/j.jbankfin.2006.10.028

McDonald, J. (2009). Using least squares and tobit in second stage DEA efficiency analyses. European Journal of Operational Research, 197(2), 792-798. http://dx.doi.org/10.1016/j.ejor.2008.07.039

Miller, S. M., \& Noulas, A. G. (1996). The technical efficiency of large bank production. Journal of Banking and Finance, 200, 495-509. http://dx.doi.org/10.1016/0378-4266(95)00017-8

Miller, S. M., \& Noulas, A. G. (1997). Portfolio mix and large-bank profitability in the USA. Applied Economics, 29, 505-512. http://dx.doi.org/10.1080/000368497326994

Parks, R. W. (1967). Efficient Estimation of a System of Regression Equations when Disturbances are Both Serially and Contemporaneously Correlated. Journal of the American Statistical Association, 62, 500-509. http://dx.doi.org/10.1080/01621459.1967.10482923

Saeed, M., \& Izzeldin, M. (2014). Examining the relationship between default risk and efficiency in Islamic and conventional banks. Journal of Economic Behavior and Organization. http://dx.doi.org/10.1016/j.jebo.2014.02.014

Sufian, F. (2009). The determinants of Islamic banks' efficiency changes: Empirical evidence from the MENA and Asian banking sectors. International Journal of Islamic and Middle Eastern Finance and Management, 2(2), 120-138.

Wooldrige, J. M. (2002). Economic Analysis of Cross Section and Panel Data. Cambridge, MA: MIT Press.

Yener, A., Carbo, S., Gardener, E., \& Molyneux, F. (2007). Examining the Relationships between Capital, Risk and Efficiency in European Banking. European Financial Management, 13(1), 49-70. http://dx.doi.org/10.1111/j.1468-036x.2006.00285.x

Yong, T., \& Christos, F. (2013). Risk, capital and efficiency in Chinese banking. Journal of International Financial Markets, Institutions and Money, 26, 378-393. http://dx.doi.org/10.1016/j.intfin.2013.07.009

\section{Appendix}

Table A1. Description of the selected sample

\begin{tabular}{llllll}
\hline Banks & $\mathrm{N}^{\circ}$ & Nature & D/F* & Creation date & Number of Observations \\
\hline Bank Islam Malaysia & 1 & Isl & D & 1983 & 7 \\
Bank Muamalat Malaysia & 2 & Isl & D & 1999 & 6 \\
Affin Islamic Bank Berhad & 3 & Isl & D & 2005 & 7 \\
CIMB Islamic Bank & 4 & Isl & D & 2005 & 7 \\
EONCAP Islamic Bank ** & 5 & Isl & D & 2005 & 5 \\
Hong Leong Islamic Bank** & 6 & Isl & D & 2005 & 7 \\
RHB Islamic Bank & 7 & Isl & D & 2005 & 7 \\
\hline
\end{tabular}




\begin{tabular}{|c|c|c|c|c|c|}
\hline AmIslamic Bank & 8 & Isl & $\mathrm{D}$ & 2006 & 6 \\
\hline My Bank Isamic & 9 & Isl & $\mathrm{D}$ & 2007 & 5 \\
\hline Alliance Islamic Bank & 10 & Isl & $\mathrm{D}$ & 2007 & 5 \\
\hline Public Islamic Bank & 11 & Isl & $\mathrm{D}$ & 2008 & 5 \\
\hline Kuwait Finance House & 12 & Isl & $\mathrm{F}$ & 2004 & 7 \\
\hline Al Rajhi Banking & 13 & Isl & $\mathrm{F}$ & 2006 & 7 \\
\hline Asian Finance Bank & 14 & Isl & $\mathrm{F}$ & 2006 & 7 \\
\hline OCBC Al Amin Bank Berhad & 15 & Isl & $\mathrm{F}$ & 2008 & 5 \\
\hline Standard Chartered & 16 & Isl & $\mathrm{F}$ & 2008 & 5 \\
\hline HSBC Amanah & 17 & Isl & $\mathrm{F}$ & 2008 & 5 \\
\hline Hong Leong Bank & 18 & Conv & $\mathrm{D}$ & 1934 & 7 \\
\hline Maybankberhad & 19 & Conv & $\mathrm{D}$ & 1960 & 7 \\
\hline Public Bank Berhad & 20 & Conv & $\mathrm{D}$ & 1960 & 7 \\
\hline Am Bank Berhad & 21 & Conv & $\mathrm{D}$ & 1975 & 7 \\
\hline RHB Bank & 22 & Conv & $\mathrm{D}$ & 1997 & 7 \\
\hline Affin Bank Berhad & 23 & Conv & $\mathrm{D}$ & 2001 & 7 \\
\hline Alliance Bank Berhad & 24 & Conv & $\mathrm{D}$ & 2001 & 7 \\
\hline Bongkok Bank Berhad & 25 & Conv & $\mathrm{F}$ & 1959 & 7 \\
\hline JP Morgan Chase Berhad & 26 & Conv & $\mathrm{F}$ & 1964 & 7 \\
\hline Deutsche Bank Berhad & 27 & Conv & $\mathrm{F}$ & 1967 & 7 \\
\hline Standard Chartered Bank Malaysia & 28 & Conv & $\mathrm{F}$ & 1984 & 7 \\
\hline United Overseas Bank Berhad & 29 & Conv & $\mathrm{F}$ & 1993 & 7 \\
\hline Bank of TokoyoBerhad & 30 & Conv & $\mathrm{F}$ & 1994 & 7 \\
\hline HSBC Bank & 31 & Conv & $\mathrm{F}$ & 1994 & 7 \\
\hline OCBC Bank Berhad & 32 & Conv & $\mathrm{F}$ & 1994 & 7 \\
\hline The Bank of Nova Scotia Berhad & 33 & Conv & $\mathrm{F}$ & 1994 & 7 \\
\hline Bank of China Berhad & 34 & Conv & $\mathrm{F}$ & 2001 & 6 \\
\hline The Royal Bank of Scotland Berhad & 35 & Conv & $\mathrm{F}$ & 2007 & 7 \\
\hline $\begin{array}{l}\text { Industrial and Commercial Bank of } \\
\text { China }\end{array}$ & 36 & Conv & $\mathrm{F}$ & 2010 & 3 \\
\hline BNP Paris Malaysia Berhad & 37 & Conv & $\mathrm{F}$ & 2010 & 2 \\
\hline Total & 37 & & & & 233 \\
\hline
\end{tabular}

Isl: Islamic; Conv: Conventional.

*Domestic or foreign bank;

** The bank Hong Leong Islamic Bank completed in November 2011 its merger with the EONCAP Islamic Bank.

Table A2. The correlation matrix

\begin{tabular}{|c|c|c|c|c|c|c|c|c|c|c|c|c|c|c|c|}
\hline & ROE & NFIM & ROD & IETD & IITE & GNPF & FTD & CTD & RWCR & LTSC & Islamic & Assets & Lerner & GGDP & NHPI \\
\hline ROE & 1,000 & & & & & & & & & & & & & & \\
\hline NFIM & 0,092 & 1,000 & & & & & & & & & & & & & \\
\hline ROD & 0,161 & 0,160 & 1,0000 & & & & & & & & & & & & \\
\hline IETD & 0,002 & 0,131 & 0,1923 & 1,0000 & & & & & & & & & & & \\
\hline IITE & $-0,026$ & 0,110 & $-0,119$ & 0,083 & 1,000 & & & & & & & & & & \\
\hline GNPF & $-0,329$ & $-0,041$ & $-0,006$ & 0,030 & $-0,056$ & 1,000 & & & & & & & & & \\
\hline FTD & 0,013 & $-0,191$ & 0,150 & 0,529 & $-0,269$ & $-0,027$ & 1,000 & & & & & & & & \\
\hline CTD & $-0,055$ & 0,089 & 0,044 & 0,423 & 0,313 & $-0,106$ & 0,138 & 1,000 & & & & & & & \\
\hline RWCR & $-0,058$ & $-0,063$ & $-0,383$ & 0,000 & 0,173 & $-0,157$ & $-0,112$ & 0,474 & 1,000 & & & & & & \\
\hline LTSC & 0,158 & 0,254 & 0,056 & $-0,148$ & $-0,052$ & $-0,144$ & $-0,028$ & $-0,172$ & $-0,172$ & 1,000 & & & & & \\
\hline Islamic & $-0,122$ & $-0,523$ & $-0,142$ & $-0,192$ & $-0,110$ & 0,100 & $-0,009$ & $-0,147$ & $-0,056$ & $-0,118$ & 1,000 & & & & \\
\hline Assets & 0,120 & 0,137 & 0,046 & $-0,152$ & $-0,121$ & $-0,039$ & $-0,007$ & $-0,246$ & $-0,171$ & 0,163 & $-0,343$ & 1,000 & & & \\
\hline Lerner & 0,077 & 0,102 & 0,091 & 0,024 & $-0,022$ & 0,029 & 0,089 & $-0,117$ & $-0,301$ & 0,121 & $-0,209$ & 0,120 & 1,000 & & \\
\hline GGDP & $-0,010$ & 0,062 & $-0,017$ & 0,110 & 0,051 & 0,029 & 0,017 & 0,076 & 0,069 & 0,005 & $-0,037$ & 0,016 & 0,003 & 1,000 & \\
\hline NHPI & 0,087 & $-0,051$ & 0,056 & $-0,138$ & 0,047 & $-0,220$ & $-0,012$ & 0,045 & 0,058 & 0,095 & $-0,005$ & 0,094 & $-0,032$ & 0,320 & 1,000 \\
\hline
\end{tabular}


Table A3. Centered and uncentered Variance Inflation Factors (VIFs)

\begin{tabular}{llllll}
\hline Variables & Centered VIF & 1/VIF & Variables & Uncentered VIF & $1 /$ VIF \\
\hline IETD & 2,12 & 0,471363 & IETD & 5,36 & 0,186492 \\
CTD & 1,99 & 0,503402 & FTD & 5,26 & 0,190280 \\
RWCR & 1,97 & 0,506703 & GGDP & 4,56 & 0,219178 \\
FTD & 1,88 & 0,531142 & NFIM & 3,19 & 0,313072 \\
Islamic & 1,80 & 0,555934 & CTD & 2,75 & 0,363197 \\
NFIM & 1,69 & 0,591772 & RWCR & 2,66 & 0,375282 \\
ROD & 1,40 & 0,716129 & NHPI & 2,30 & 0,434903 \\
Assets & 1,34 & 0,747018 & Islamic & 2,06 & 0,486044 \\
IITE & 1,33 & 0,754673 & GNPF & 2,04 & 0,489660 \\
NHPI & 1,28 & 0,778738 & Assets & 1,71 & 0,585760 \\
GNPF & 1,26 & 0,795792 & LTSC & 1,70 & 0,588492 \\
LTSC & 1,21 & 0,823794 & ITTE & 1,46 & 0,686943 \\
ROE & 1,19 & 0,838158 & ROD & 1,40 & 0,714862 \\
Lerner & 1,19 & 0,839490 & ROE & 1,27 & 0,784732 \\
GGDP & 1,18 & 0,846060 & Lerner & 1,22 & 0,820814 \\
Mean VIF & 1,52 & Mean VIF & 2,60 & \\
\hline
\end{tabular}

Table A4. Table of condition indexes and variance decomposition

\begin{tabular}{ccccccccccccccccccc}
\hline \multicolumn{10}{c}{ Indexes } & \multicolumn{10}{c}{ Variance decomposition } \\
\hline & Cons & ROE & NFIM & ROD & IETD & IITE & GNPF & FTD & CTD & RWCR & LTSC & Islamic & Assets & Lerner & GGD.NHPI \\
\hline 1 & 1,00 & 0,00 & 0,00 & 0,00 & 0,00 & 0,00 & 0,00 & 0,00 & 0,00 & 0,00 & 0,00 & 0,00 & 0,00 & 0,00 & 0,00 & 0,00 & 0,00 \\
2 & 2,03 & 0,00 & 0,05 & 0,00 & 0,08 & 0,00 & 0,02 & 0,00 & 0,00 & 0,02 & 0,03 & 0,03 & 0,01 & 0,03 & 0,08 & 0,00 & 0,00 \\
3 & 2,42 & 0,00 & 0,09 & 0,00 & 0,02 & 0,00 & 0,11 & 0,06 & 0,00 & 0,05 & 0,01 & 0,00 & 0,05 & 0,00 & 0,01 & 0,00 & 0,00 \\
4 & 2,54 & 0,00 & 0,08 & 0,00 & 0,23 & 0,02 & 0,00 & 0,03 & 0,00 & 0,03 & 0,01 & 0,06 & 0,00 & 0,04 & 0,01 & 0,00 & 0,01 \\
5 & 2,64 & 0,00 & 0,14 & 0,00 & 0,10 & 0,00 & 0,08 & 0,03 & 0,00 & 0,00 & 0,00 & 0,00 & 0,02 & 0,01 & 0,32 & 0,00 & 0,01 \\
6 & 3,03 & 0,00 & 0,17 & 0,02 & 0,05 & 0,00 & 0,00 & 0,00 & 0,01 & 0,00 & 0,00 & 0,01 & 0,08 & 0,14 & 0,32 & 0,00 & 0,00 \\
7 & 3,11 & 0,00 & 0,00 & 0,00 & 0,06 & 0,01 & 0,36 & 0,00 & 0,01 & 0,02 & 0,05 & 0,06 & 0,05 & 0,05 & 0,02 & 0,00 & 0,02 \\
8 & 3,41 & 0,00 & 0,00 & 0,02 & 0,01 & 0,01 & 0,03 & 0,00 & 0,00 & 0,00 & 0,00 & 0,41 & 0,00 & 0,13 & 0,02 & 0,01 & 0,20 \\
9 & 3,42 & 0,00 & 0,30 & 0,00 & 0,02 & 0,00 & 0,08 & 0,11 & 0,00 & 0,02 & 0,01 & 0,13 & 0,00 & 0,04 & 0,04 & 0,00 & 0,19 \\
10 & 4,15 & 0,00 & 0,06 & 0,05 & 0,04 & 0,06 & 0,10 & 0,24 & 0,07 & 0,00 & 0,10 & 0,02 & 0,01 & 0,12 & 0,03 & 0,01 & 0,02 \\
11 & 4,47 & 0,00 & 0,00 & 0,06 & 0,17 & 0,05 & 0,00 & 0,01 & 0,00 & 0,10 & 0,11 & 0,06 & 0,12 & 0,23 & 0,07 & 0,04 & 0,10 \\
12 & 5,08 & 0,01 & 0,09 & 0,21 & 0,05 & 0,00 & 0,00 & 0,42 & 0,01 & 0,09 & 0,04 & 0,14 & 0,13 & 0,00 & 0,04 & 0,02 & 0,13 \\
13 & 5,65 & 0,00 & 0,01 & 0,11 & 0,18 & 0,01 & 0,11 & 0,00 & 0,05 & 0,55 & 0,42 & 0,02 & 0,10 & 0,04 & 0,00 & 0,01 & 0,01 \\
14 & 6,27 & 0,00 & 0,00 & 0,11 & 0,00 & 0,00 & 0,01 & 0,01 & 0,05 & 0,04 & 0,03 & 0,03 & 0,01 & 0,01 & 0,00 & 0,83 & 0,21 \\
15 & 8,04 & 0,01 & 0,00 & 0,02 & 0,00 & 0,84 & 0,04 & 0,00 & 0,54 & 0,06 & 0,06 & 0,04 & 0,07 & 0,06 & 0,02 & 0,03 & 0,07 \\
16 & 13,15 & 0,98 & 0,01 & 0,38 & 0,01 & 0,00 & 0,06 & 0,08 & 0,25 & 0,01 & 0,14 & 0,00 & 0,37 & 0,09 & 0,00 & 0,04 & 0,01 \\
\hline
\end{tabular}

\section{Notes}

Note 1. Financial stability and payment systems report 2012.

Note 2. Financial stability and payment systems report 2012.

Note 3. The market share of the five largest Malaysian banking groups has increased to reach $61,1 \%$ in 2007 compared to52,5\% in 2001.

Note 4. The quiet life hypothesis, John Hicks.

Note 5. A more detailed analysis of the calculation of efficiency scores in the Malaysian context using the meta-frontier approach is presented in Ghroubi and Abaoub (2016).

Note 6. The resolution of the two optimisation programs (1) and (2) is carried out by the genetic algorithm method.

Note 7. The term "interest" is replaced by profit or by commission income in the case of Islamic banks.

Note 8. Tables 7 (A2), (A3) and (A4) of the appendix represent respectively the correlation matrix, the results of the centered and uncentered Variance Inflation Factors (VIFs) and the table of condition indexes and variance 


\section{decomposition.}

Note 9. A positive effect of liquidity on cost efficiency is also validated by several previous studies conducted in the context of IBs and European banks (Hasan and Dridi (2010)).

Note 10. To evaluate the effect of economic growth, Saeed and Izzeldin (2014) use GDP per capita.

\section{Copyrights}

Copyright for this article is retained by the author(s), with first publication rights granted to the journal.

This is an open-access article distributed under the terms and conditions of the Creative Commons Attribution license (http://creativecommons.org/licenses/by/3.0/). 